\title{
UNIVERSITYOF
}

FORWARD

THINKING

WESTMINSTER用

WestminsterResearch

http://www.westminster.ac.uk/westminsterresearch

The role of geographical proximity in the establishment and

development of science parks - evidence from Nanjing, China

Guo, Y. and Verdini, G.

This is an Accepted Manuscript of an article published by Taylor \& Francis in Asian Geographer, 32 (2) 117-133. The final definitive version is available online: http://www.tandfonline.com/https://dx.doi.org/10.1080/10225706.2015.1079726."

(C) Taylor \& Francis Inc.

The WestminsterResearch online digital archive at the University of Westminster aims to make the research output of the University available to a wider audience. Copyright and Moral Rights remain with the authors and/or copyright owners.

Whilst further distribution of specific materials from within this archive is forbidden, you may freely distribute the URL of WestminsterResearch: ((http://westminsterresearch.wmin.ac.uk/)).

In case of abuse or copyright appearing without permission e-mail repository@westminster.ac.uk 


\section{The Role of Geographical Proximity in the Establishment and Development of Science Parks -Evidence from Nanjing, China}

Citation: Yu, G., Verdini, G. (2015), 'The Role of Geographical Proximity in the Establishment and Development of Science Park. Evidence from Nanjing, China', Asian Geographer, 32, 117-133

\section{Abstract}

The emergence of science parks is a relatively new phenomenon in China. Apart from the widely debated topics of university-industry linkages, collaboration among firms and spontaneous/policy-driven science parks, the development of science parks in China also has several distinguishing characteristics, such as their ambiguous linkage with urban expansion and their hierarchical structuring pattern. This paper attempts to discuss the motivation and efficiency of spatial proximity in science park development and to explore the role of universities in science parks, the function of science parks as a government project and a case study of location choice by on-site firms. The qualitative analysis, based on indepth interviews with tenant firm managers and district-level government officers in Jiangning, Nanjing, is used as a basis for discussion.

\section{Keywords:}

Geographical Proximity; Science Parks; China

\section{Introduction}

As a platform for highly skilled individuals from high-tech sectors, research institutions and, possibly, governments and financial services, science parks have long been expected to promote regional innovation and economic growth. However, several studies conclude that it is unlikely that science parks can deliver the following widely expected benefits: knowledge spillover and technology transfer (Storey and Tether, 1998), employment growth in high-tech fields (Shearmur and Doloreux, 2000), operational collaboration between technology industries and research institutions (Malerba et al., 1995; Phillips and Yeung, 2003) and extraordinary growth or performance of on-park firms (Bakouros et al., 2002). Moreover, researchers also raise concerns over the flourishing policy-driven science parks: the side effects of government overinvolvement (Anttiroiko, 2009) and the diversified rationales behind government input (Felsenstein, 1994; Koh et al., 2005). If the importance of physical proximity to a research institution is rather marginal in science parks, will it result in a weak role for academia in science park development? If hightech companies with a short distance from a policy-driven science park do not tend to exchange knowledge and build collaboration with the park, is the science park a failure as a government-led project? If a science park is not to contribute to creating an innovation milieu for on-site firms, then what motivates high-tech companies? The aim of this paper is to discuss these questions and attempt to answer them. 
Unlike in Western nations, where the instigators of science parks can be universities, local authorities or public development agencies (Macdonald, 1987; Quintas et al., 1992), it is believed that in China, governments at different administrative levels act as major initiators of science parks, which frequently serve as policy instruments to stimulate the development in high-tech sector (Sutherland, 2005; Tan, 2006; Qian, 2007; Hu et al., 2010). Led by the first 53 state-level science parks built during the 1980s and 1990s, there were 129 national-level science and industry parks as of 2015, 107 provincial-level science parks as of 2007 and no reliable data about municipal or lower administrative levels (Chen, 2009; MOST, 2015). Furthermore, there is a unique "sub-park" mode in China, which can be defined as essentially a territorial system of a big park or zone with parks scattered inside, often nurturing the growth of these individual parks. This feature can be widely witnessed in different types of economic and technological development zones and high-tech industrial development zones.

The paper first briefly reviews the literature on science parks, focussing on university-industry linkages, collaborations among firms and the classification of spontaneous and policy-driven science parks. Section 2 describes the government-led development of high-tech sectors and science parks in China. Section 3 introduces the methodology. Section 4 provides related background of Nanjing city, followed by a discussion of empirical findings with topics on the conceptualisation of science parks, location choice of firms, the role of spatial proximity between companies and universities, and the role of spatial proximity among firms.

\section{A review on the development of science parks}

\section{1) Definition, University-Industry linkages, collaboration among firms}

From a conventional viewpoint, universities play a vital role in society as producers of knowledge through research and teaching. In recent decades, the "third mission" of universities has been increasingly promoted: to directly commercialise theoretical science and basic research activities with a view to the operation and production of industry and further to the market (Chen and Choi, 2004; Vedovello, 1997). Meanwhile, locales with higher education institutions are expected to have better job generation and wealth creation (Malecki, 1991). The proliferation of science parks began at prestigious universities in the US in the early 1950s, when Stanford Research Park, Cornell Business \& Technology Park and the Research Triangle Park were established (Link and Link, 2003; Link and Scott, 2006). Only in the late 1980s did the establishment of science parks become commonplace in US and UK. Unlike in the US, where the increase in newly created parks coincided with public proposals to encourage academyindustry linkages, increases in industrial R\&D spending and the establishment of research partnerships, the science park boom in the UK was driven by swinging cuts in university funding and the resulting high levels of unemployment (Quintas et al., 1992; Link and Scott, 2006).

The term "science park" is common and popular worldwide. Alternative terms such as "business park", "technology park", "research park and innovation centre" 
are also in use to describe similar developments (Monck et al., 1988). Although a number of definitions have been applied to science parks by professional associations such as the International Association of Science Parks and the United National Educational, Scientific and Cultural Organization, Link and Scott (2006) argue that each definition has limitations in describing a particular phenomenon: some of them overemphasise a one-way flow of knowledge from academia to industry, while others confuse the differences between the definition and the objective.

The relationship between university and industry can be established in many forms, from formal cooperation for research purposes to an informal network for information sharing. Monck et al. (1988) summarise that the academicindustry linkages might include knowledge transfer and professional reallocation between education institutes and private firms; technical support by university researchers and students; mutual contracts for development, design, analysis, testing and evaluation; and access to university facilities.

Moreover, since the concept of the science parks originally developed at prestigious universities in the US such as Stanford, Harvard and MIT, it is believed that firms in proximity to universities can benefit from technological spillovers and industrial R\&D labs, so they tend to concentrate in those areas where levels of university research are advanced (Jaffe, 1986; Beeson and Montgomery, 1990; Bania et al., 1992; Vedovello, 1997). Despite a large volume of studies valuing the importance of universities and research institutions, the reality turns out to be that the academia does not always play a significant role in science parks. For instance, Storey and Tether (1998) note that in Germany, many of the Business and Technology Centres do not focus exclusively upon research or science-based firms; rather, they are generally seen as propertybased initiatives. Furthermore, in the early 1990s, the UK Science Park Association relaxed its academic link criterion on associating parks with an important research base (Quintas et al., 1992). In addition, in Italy, the interface between academia and industry within science parks is considered particularly weak (Malerba et al., 1995).

The agglomeration of academic scientists, engineers and entrepreneurs is expected to create an innovative milieu and promote synergy not only between universities and technology firms but also among the firms themselves (Chan and Lau, 2005). In the context of science parks, it is claimed that the knowledge required in high-tech or innovative firms tends to be tacit, complex and systematic; therefore, face-to-face communications and inter-personal contacts between individuals can significantly facilitate the diffusion and transmission of knowledge (Arundel and Geuna, 2004; Smith, 2007). Although Antonelli (1999) and Roberts (2000) argue that globalisation has facilitated the transmission of knowledge and reduced the importance of geographical proximity, other studies are strongly against this. For example, Saviotti (1998) models a negative correlation between the degree of knowledge codification and the distance from the technological frontier, arguing that highly-codified knowledge can be better transmitted over a short distance. Furthermore, Leamer and Storper (2001 p.1) propose that, with rapid economic development, the manner of communication 
increasingly depends on "handshake" interactions rather than the "conversational" interactions that can be achieved via the Internet.

\section{2) Spontaneous and policy-driven science parks}

"Clusters" are classified into two broad types: (1) spontaneous clusters, which are born and developed as a result of the existing concentration of key factors, without direct input from the public sector, and (2) policy-driven clusters, which are promoted by government with a strong determination to undertake actions either as a response to an industrial crisis or as a deliberate strategy to foster a specific sector (Chiesa and Chiaroni, 2005). In a similar vein, most science parks are policy-driven and initiated by government support, whereas spontaneous situations such as Silicon Valley and its replication in Cambridge did not exist at first but were established as a result of later initiatives (Storey and Tether, 1998; Chiesa and Chiaroni, 2005; Huang et al., 2012). The classification of spontaneous and policy-driven science parks can be also referred to with a controversial question about which occurs first: science parks or an established local economic and technology development environment (Appold, 2004).

Since the 1980s, many governments in both developed and developing countries have made great efforts to build science parks, attempting to "grow the next Silicon Valley" (Miller and Cote, 1987). Temporally and spatially, the development of policy-driven parks swept the world, from the US and the UK to advanced European countries, and to Southern European countries as well as other developing countries. During the 1980s and early 1990s, New TechnologyBased Firms (NTBFs) in European Union countries attracted particular attention in the policy area, and the science park was seen as a valued and prestigious location for their establishment. Nonetheless, a series of empirical investigations in the UK, Netherlands and Germany have revealed that the significance of science park to the growth and survival of an NTBF is rather marginal compared to firms elsewhere (Westhead and Storey, 1994; Bartels and Wolff, 1993; Van Tilburg and Voustman, 1994; Sternberg, 1997).

Perceived as a vehicle for technology-based economic growth and development, science parks in Western countries have significantly influenced their counterparts in Asian countries (Vaidy, 2008). Beginning with the first science park built in Japan, a thriving number of science parks have been built by Asian governments since the mid-1980s (Phan, et al., 2005). Although policy-driven parks may enjoy a wide range of supportive services and resources, overinvolvement of the government can result in serious problems, such as unplanned budget overruns, overrepresentation of on-park government bureaucracy and a weak innovation system (Anttiroiko, 2009). Intriguingly, there are outstanding variances between "park models" and "park followers". For example, in many Asian countries, such as Singapore and Malaysia, the rationale behind governments' activities in investing in and developing science parks is more complex than general objectives such as nurturing the development of high-tech industry, encouraging academia-industry linkages and stimulating local economic development-the governments also have other targets in mind, including (a) to raise the level of technological sophistication in local industries; (b) to attract foreign direct investments and (c) to speed up the 
transition from a labour-intensive to a knowledge-intensive economy (Felsenstein, 1994; Koh et al., 2005). Moreover, the distinction between Western parks and Asian parks also lies in what a science park is like: in the US, a science park looks like an actual park, in which high-tech firms occupy high-quality buildings, whereas in the UK, a science park can be as small as a single building (Macdonald, 1987). In contrast, public officials in many Asian countries are keen to provide high-quality infrastructure for science park development. The presence of well-established physical infrastructures, even with tenuous linkages to universities and research institutions, can still signal the strong commitment of government to developing high-technology industries (Koh et al., 2005). A direct consequence of this signalling motive in Singapore is that owners choose to locate their firms in science parks to take advantage of physical infrastructure and preferential governmental policies, rather than to establish links with universities or other tenant firms (Phillips and Yeung, 2003). The strong motivation of image building is also especially true in developing countries, where firms' growth is decisively determined by conventional production and locational factors instead of knowledge and innovation (Felsentstein, 1994; Cheng et al., 2013). Undoubtedly, it may be an oversimplification to generalise science parks worldwide into two groups, considering that they all have internal differentiations even while they share common ground. In order to observe relatively consistent conditions, the next section focuses particularly on China, where science parks seem to have developed in a hierarchical fashion.

\section{The government-led hierarchical structure of science parks in China}

Since the early 1980s, the central government in China has launched a series of programs, such as the National High-Tech Research and Development Program (program 863), the National Torch Program, the Key Technologies R\&D Program, the National Basic Research Program (Program 973), the National Science and Technology Infrastructure Program, the National Sparkling Program etc. (Hu et al., 2010). The primary mission of the National Torch Program is to promote the diffusion of new technologies to production and the market (Huang et al., 2013). Representing the top of the hierarchical structure of science parks in China, the Torch Program grew quickly in the 1990s, followed by the development of university towns in the early 2000s (Chen, 2009; Wei, 2015). One of the distinguishing characteristics in China is that the political administrative system (national, provincial, municipal and district/local) has given a hierarchical structuring pattern to the development of science parks. Although the administrative level is assigned to most science parks as a certificate, there have been quite a few regulations on categorising and organising these groups.

Science parks under the Torch Program have been widely analysed either in selected case studies or in a systematic way, but the empirical results are not always consistent or coherent. Using a qualitative approach, Walcott (2002) finds that state-level parks can create a privileged space in which more favourable conditions are provided for product development and manufacturing compared with off-park situations. Through semi-structured interviews with key 
stakeholders in large-scale science parks, Sutherland (2005) concludes that parks in China cannot yet be considered as clusters of knowledge innovation and academia-industry cooperation because they tend increasingly to import foreign technology and attract foreign direct investment rather than promoting indigenous firms and technologies. Recent research has shifted to the quantitative approach, conducting evaluations and analyses on the performance of China's science parks. Based on data from 53 state-level science parks in China from 2004 to 2006, Hu et al. (2010) put forward that local public assets such as transportation systems, hospitals, education and police can contribute to the efficiency of the parks. Moreover, they also suggest the successful administrative experience in the east coast area should be a model for the central and west coast areas because the performance of science parks in the east is generally better than the central and western parts of China. Using firms' data in Zhongguancun Science Parks, Ramirez et al. (2013) point out that the labour mobility of high-skilled employees among firms can make a positive impact on the performance of a science park, especially when this mobility is local instead of inter-regional.

Apart from the two major types, including economic and technological development zones and high-tech industrial development zones, the Chinese government has continued to introduce new types, such as tax-free zones and export-processing zones, in order to set up preferential politics and attract financial capital (Wei, 2015). Cheng et al. (2013) argue that, in China, industrial parks focus more on production, whereas science parks centre on-but are not limited to-technology-oriented activities; in practice, however, the boundaries among different types of zones, districts and parks are quite unclear.

Furthermore, what we know about Chinese science parks is largely based upon empirical studies of early science parks. However, few studies have investigated lesser-known ones. Within the hierarchical structure of China's parks, the "subpark" model is a unique feature. It can essentially be defined as a territorial system in which a big park contains several smaller parks, often nurturing the growth of these individual parks. The large park itself, therefore, can be seen as a "seedbed" for small science parks. The most famous and successful science park in China, Zhongguancun, is a typical example of the "sub-park" model because it accommodates 26 university science parks and 34 returnee entrepreneur science parks. It is important to note that Beijing is home to a number of China's top academic institutions, which allows Zhongguancun benefit not only from a local pool of skilled labour but also from proximity to prestigious universities. What is special, however, is the fact that Zhongguancun, established in 1988 as the first state-level park, is actually a product of both the spontaneous emergence of many high-tech firms and subsequent governmental support (Sutherland, 2005). Established on the provision of a local pool of skill and on the basis of existing entrepreneurial activities, the astonishing growth of Zhongguancun was a real imitation of the Silicon Valley model, but not a typical one in China (Wang and Wang, 1998). In contrast to the Western notion that a science park can exist even in a single building, a Chinese science park like Zhongguancun can occupy as much as $100 \mathrm{~km}^{2}$ (Cao, 2004). 
The emergence of science parks in China has coincided with the end of the period during which firms' location was directly influenced by socialist ideology, national defence and economic pragmatism. It has also coincided with the start of a period in which firms are driven by both policy incentives, such as land support and tax exemption, and market forces, such as high profits and low costs (Lo, 1987; He et al., 2007). Cheng et al. (2013) suggest that at least two factors contribute to science parks' influence on the location choice of high-tech firms. On the one hand, science parks in China have not yet focussed on indigenous innovation because of the status of national technology advancement (Cao, 2004); therefore, most on-park firms are still attracted by low production costs and sub-contracting opportunities from adjacent foreign technology firms. On the other hand, the higher administrative level a science park belongs to, the better access to preferential policy incentives it has; consequently, high-tech firms are attracted to science parks, especially those at the top of the hierarchy.

\section{Methodology}

Prior to introducing the empirical evidence, it is important to explain the methodology. A case-study approach was used to capture extensive information from key actors in the establishment and development of science parks. This study comprises 13 in-depth interviews with on-site companies' representatives and two with local governors in Jiangning Economic and Technological Development Zone (JETDZ) in the Jiangning district of Nanjing. It cannot be denied that it is of critical difficulty to conduct in-depth interviews with company owners in China. This is evidenced in the recent research on science parks in China, which adopted a case study methodology while was based purely on secondary data analysis (Huang et al., 2013; Tan, 2006; Zou and Zhao, 2014; Zhou, 2009).

Corresponding to the relationship between political administrative system and hierarchical structuring pattern, both the Jiangning district and JETDZ have gone through a process of upgrading from a county to a urban district and from municipal level to national level, in the year of 2000 and 2010 respectively. These activities are seen as representative in China especially from 2000 onwards when economic growth in China have exceptionally accelerated and large infrastructure projects such as development zones are seen as an essential mechanism for developing the new annexed urban area. Moreover, JETDZ, which owns more than ten parks and centres with different emphases and scales, can be positioned as a typical example of the aforementioned "sub-park" mode. Since all of the companies' respondents interviewed in the case study are located in one park (Cuiping Technology and Innovation Park) owned by JETDZ, this case study is a microcosm of countless small parks in China, presenting a critical reflection that goes beyond what is already known. In order to efficiently use the first-hand data, secondary data and supplemental complementary informationsuch as Nanjing's planning documents, development reports and newspaperswere also collected and reviewed. 


\section{A case study of Cuiping Technology and Innovation Park in JETDZ}

As mentioned in the introduction, this study set out with the aim of assessing the importance of geographical proximity in the establishment and development of science parks. There are three primary objectives of this research - to explore the rationale behind firms' location choice in a policy-driven science park, to investigate the significance of physical proximity to a research institution in the development of science parks and to ascertain the influence of the short distance on knowledge exchanging and collaboration building among high-tech companies. With respect to the research purposes, this section has been divided into five parts, starting with background information of the growth of science parks in the city of Nanjing and Jiangning district, as well as the interviewees' conceptualization of science parks so as to facilitate the understanding of following discussion.

\section{1) Growth of science parks in the city of Nanjing and Jiangning district}

Nanjing is the capital city of Jiangsu, one of China's richest provinces, along with Guangdong and Zhejiang. Located approximately 300 kilometres northwest of Shanghai, Nanjing is a major historical, cultural and economic centre in the Yangtze River Delta (Figure 1). As an important knowledge-intensive city in China with a strong capacity for innovation development, resource sharing and knowledge upgrading, Nanjing has 103 post-doctoral stations and 501 independent R\&D institutions at the municipal level or above (PwC, 2011). 


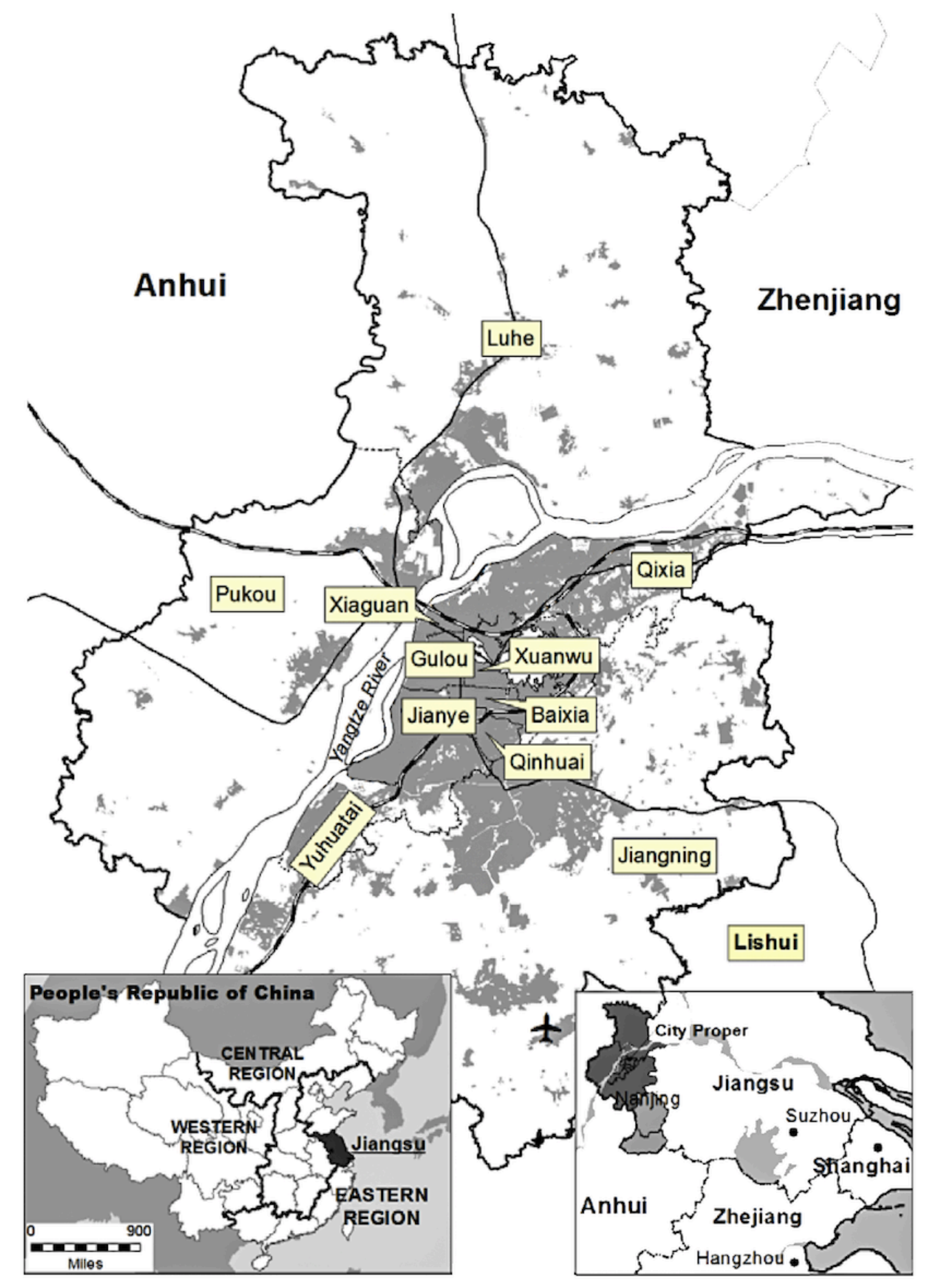

Figure.1 Location and administrative districts of Nanjing. Source: Wei, 2015, p.161. Modified by the author.

However, zone fever has swept Nanjing since the national-level Nanjing HighTech Zone was first established in 1991 under the Torch Program. Figure 2 illustrates the sparse distribution of most, if not all, of Nanjing's parks and zones, including technology parks, industrial parks, logistics bases, development zones 
etc. According to a strategic planning report about Nanjing prepared by China's National School of Administration (2004), it seems that the different types and locations of parks and zones fail to create an efficient arrangement of technological and industrial agglomeration at the municipal level. In particular, high-tech industries such as electronic information, biological and pharmaceutical chemistry and new material are found scattered across the city. For example, Nanjing has numerous so-called software parks in several urban districts, including Gulou, Xuanwu, Yuhuatai, Jiangning and Pukou, all of which take part in a fierce competition to seize promising firms (Lin, 2009). In addition, at least four urban districts name the development of biological and pharmaceutical chemistry as a priority in attracting high-tech firms into their parks and zones. The aforementioned report also criticises the fact that until the mid-2000s, Nanjing lacked favourable policies to attract overseas talents compared to Beijing, Shanghai, Guangzhou and other neighbouring cities, such as Wuxi and Suzhou. 


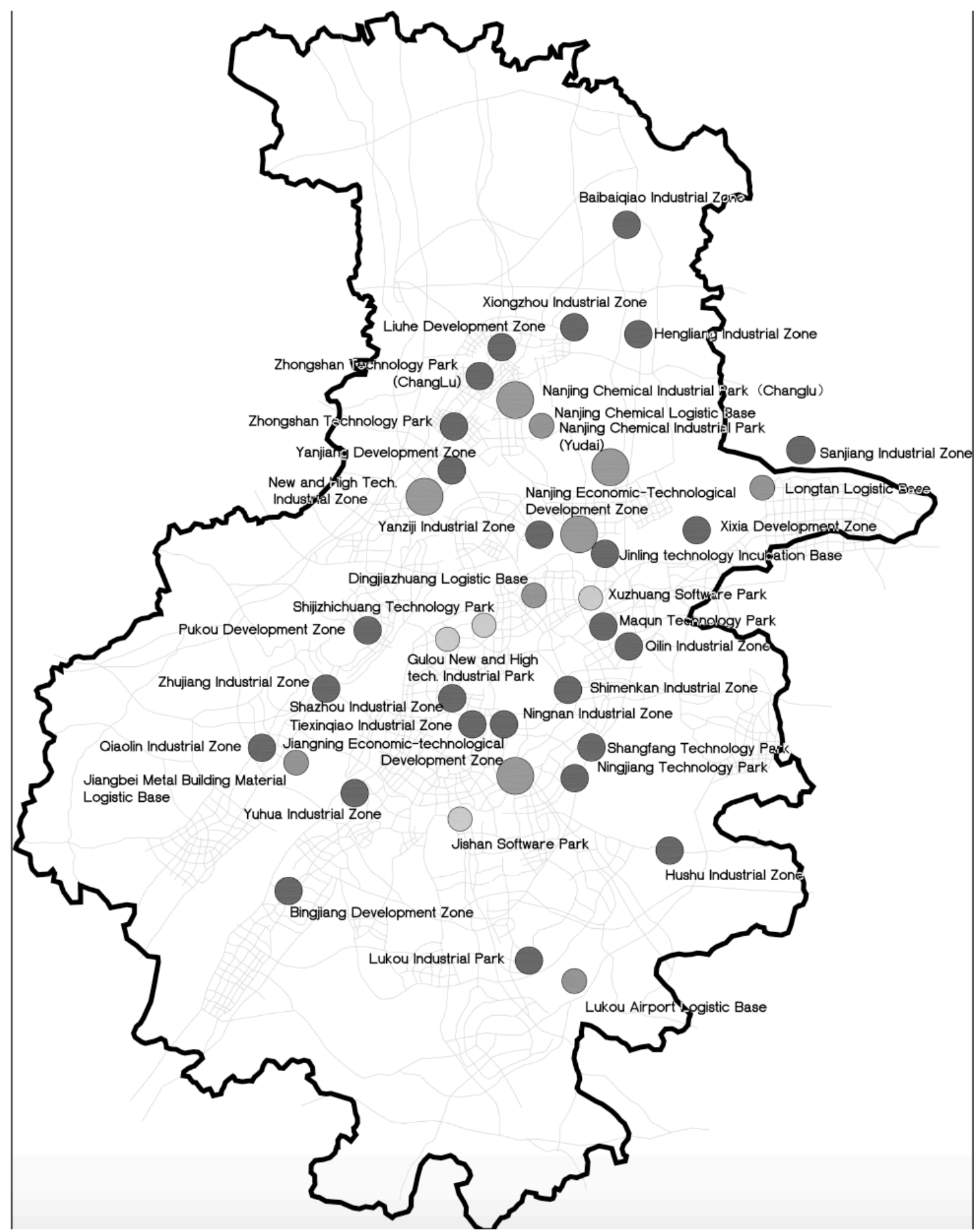

Figure 2. Dispersed industrial zones and parks in Nanjing. (Note: The status of the zones ranges from national industrial zones to town/district industrial zones). Source: Qian, 2013. p.83

In China's development, park fever and zone fever have been accompanied by administrative restructuring, a process in which central cities take over suburban land through annexing counties or towns. Nanjing is no exception. In the years 2000 and 2002, the city went through urban restructuring twice, which enlarged the city proper from $975 \mathrm{~km}^{2}$ to $4720 \mathrm{~km}^{2}$. In this process, the construction of parks and zones co-occurred with the development of university towns, resulting in a government-led coexistence of high-tech grounds and academic fields. Showing Nanjing's ambition to be known as an innovation hub 
with a knowledge-based economy, three university towns have been established in three districts - Jiangning, Pukou and Xixia - each of which faces towards different direction of the city's outskirts (Wei, 2015). University towns, however, are not only for universities, but also for the development of high-tech industries through attracting overseas returnees and technology companies. From this perspective, a significant number of science parks, technology parks and innovation parks at different administrative and scale levels are largely located in proximity to these university towns.

In response to the "Thousand Talents Program" (a program for recuiting global experts) launched by the central government and the "Shuang Chuan Program" (a program for recruiting innovative and entrepreneurial experts) launched by the Jiangsu government, the "Entrepreneurship Talents 321 Plan" was initiated by the Nanjing municipal government in 2011 with the aim to attract 3,000 "leading technological entrepreneurship talents", 200 "technological entrepreneurs" and 100 of the top thousand talents in the nation to work in Nanjing during the next five years. For most of our interviewees, especially those companies in which technology sources are from overseas, the initial motivation to locate their firms in Nanjing was the "321 Plan" promotion fair co-organised by the Nanjing municipal and district governments in Europe, North America and some developed Asian countries.

Jiangning Economic and Technological Development Zone (JETDZ) was established in 1992, and Jiangning county was rescaled to Jiangning district in the end of 2000, followed by the construction of Jiangning University Town in 2002. A direct outcome of the annexation of Jiangning county by Nanjing city is that it doubled the administrative area of the city proper and expanded the urban area to the south. According to a thematic research study (CAUPD, 2004), Jiangning district has been suggested to develop into a combination of functional residential area and technology-intensive processing industrial area in order to alleviate the residential density in the urban core and provide jobs for surplus labour in surrounding rural area. However, this thematic study is not in favour of building a university town in Jiangning for the sake of avoiding the competition for construction land between universities and industries. The other reason is that the existing Xianlin University Town located in the northeast of Nanjing already occupies $47 \mathrm{~km}^{2}$ and has been home to as many as 8 percent university students in Jiangsu province. Nonetheless, 15 universities, including prestigious ones such as South East University and Nanjing University of Aeronautics and Astronautics, have gradually been attracted to build campuses in Jiangning district.

In terms of the aforementioned sub-park mode, within JETDZ, there are more than ten parks and centres with different emphases and scales. These include National High-tech Start-up Service Centre, Overseas Returnee Start-up Centre, Cuiping Technology and Innovation Park, China Wireless Valley, Jiangsu Software Park, Hsinghua Technological Park, Cloud Computing Centre, Communication System Centre and Life Science Industrial Centre. Cuiping Technology and Innovation Park, which contains three buildings with total gross floor area of $0.24 \mathrm{~km}^{2}$, is selected as a case study in this paper. 


\section{2) Conceptualization of science parks}

The development of science parks in China, compared with that of Western countries, is still a new phenomenon. An open-ended question of the conceptualization of science parks can capture the attitudes of high-tech companies' owners and facilitate our understanding of their choice of location afterwards. In line with the initial purpose of establishing JETDZ, all 13 of the companies involved in our interviews belonged to high-tech industries, ranging from optoelectronics and computer science to new materials and biological pharmaceutical chemistry. Most of the owners established their companies with self-raised funds, while a few of them received venture capital investment; only one of the interviewed companies was state owned. Additionally, the technology sources of more than half of the investigated companies were from overseas and the rest of them were from high-level research institutions in China. Due to their educational backgrounds, most interviewees had a rich knowledge of science parks, especially those who had an overseas background, although the perspectives were different.

In my understanding, a science park is a fixed geographical location that has been led and guided by government. The establishment of science parks should comply with the local economic development strategy and also local resources such as infrastructure facilities and human capital. At present, universities not only focus on teaching and research, but also attempt to transfer knowledge into market products. Thus, I think industries have a responsibility to be the platforms for research institutions and universities to achieve the commercial goal. At this point, the science park is a place to make the interaction among study, research and production happen. (CEO, Intple Co. Ltd, 2012)

Science Parks such as Cambridge Science Park and Silicon Valley have been popular for a long time in developed countries. From my perspective, the surrounding research institutes initiate science parks, through which university professors or institute researchers have their own spin-offs to promote the R\&D activities in the park. In China, the official definition of a science park is unclear because sometimes there is no well-defined boundary between science parks and industrial parks. Moreover, it is becoming "a fashion" to create science parks affiliated with universities, especially in their newly established campuses, although the pragmatic function of science parks is often ignored. (Director, Yuda Co. Ltd, 2012)

It is interesting that all the company representatives mentioned that the main function of science parks was to achieve "the cooperation of enterprises, universities and research institutions" (chan xue yan jiehe), which is a slogan used by the central government to encourage the development of science parks across the country in recent years.

\section{3) Location choice of firms}

Compared with the criticism on the role of government in the establishment and development of science parks in other countries, the in-park companies 
generally recognised and appreciated the effort made by different administrative levels of government. In terms of the reasons for choosing Nanjing, most attention was equally paid to the preferable policy incentives given by Nanjing municipal government and the favourable education and research resources at the city level. In particular, all of the interviewees who were overseas returnees mentioned that the "321 Plan" Promotion Fair organised by the Nanjing municipal government abroad played a significant role in their location decision. However, as for choosing Jiangning district, interviewees reiterated the fierce competition between different districts in securing high-tech firms.

In the initial preparation period, we plan to locate our firm in a science park belonging to another district in Nanjing. The turning point is an event held by the Nanjing municipal government in the US, when the local governors of Jiangning district were extremely proactive in introducing us to the beneficial policies over other districts such as tax deduction and free usage of the plant for three years, as well as promoting urban amenity and other companies and universities located in Jiangning. Finally, we established our company here. (CEO, Intple Co. Ltd, 2012)

To be honest, initially we did not plan to join any science park since I was abroad for a long time and did not want to get involved in a governmentled project. However, the most attractive advantage of joining CSP is I do not need to worry about the infrastructure facilities and the office buildings because the government is in charge. Compared with other science parks located in the urban centre district of Nanjing, I prefer Jiangning because there are more available lands in the urban fringe so local government can support us to expand firm scale as they promised. Land is an important issue in China, as we all know. Moreover, although Jiangning district is not crowded, the transportation system is properly developed. I prefer wellestablished public transportation. (Director, Yuda Co. Ltd, 2012)

Apart from the vital role of district government, interviewees also gave other explanations. For example, some companies thought the location of Jiangning offered easy access to Nanjing airport and the national motorway. Thus, a formal meeting with other companies located in the Shanghai or Suzhou-WuxiChangzhou metropolitan area (the top three cities in economic development in Jiangsu Province) could be achieved within one day. Other companies placed significant value on a large number of university graduates in Nanjing. In addition, an interesting comment was from a manager relocated from the headquarters in Beijing.

Compared with Beijing, I think the air pollution is much better in Nanjing. Especially since Jiangning was previously a rural area in the urban outskirts and the municipal government does not put heavy industry in this area, the natural environment is pleasant. (Manager, The Future Internet Technology Co., Ltd, 2012)

Except for the acknowledgements, there was one firm which had already been planned to move out of JETDZ to another district in Nanjing, because there was a potential to build formal relationships with research institutions. According to 
the director of this firm, who preferred to remain anonymous in this context, although their core technicians were slowly moving to the new site, the office would be kept for storage use.

\section{4) The role of spatial proximity between companies and universities}

Although it seems that all the companies recognise the role of universities and research institutions in a science park, in fact, the real interaction between the two in JETDZ was rather limited. After we consolidated the data, two trends in particular drew our attention. In the 13 companies we interviewed, there were four companies that had no links with universities located in Jiangning, even in the city of Nanjing.

We only build formal relationships with Tianjing University because our CEO was a professor there and he is still running a research centre in Tianjing University. I think the reason why we have no linkage with local universities is because of the specific industry our firm is in. (Market Manager, MDTP Optics Co., Ltd, 2012)

Although I graduated from the school of environment in Nanjing University, our firm has no linkages with any universities in Nanjing. The industry of soil remediation is still in the early phase and the underlying information still tends to be confidential in China. Therefore, we can only build relationships with national-level research institutions such as China Academy of Science. (General Manager, Jiangsu ZS Environment Remediation Co., Ltd, 2012)

The other trend is that the other nine companies that cooperated with on-site universities only concentrated on three of the 12 universities. Undoubtedly, these three are the top universities in China in terms of their teaching and research levels. The companies cooperate with them by sharing knowledge and inviting professors and students to conduct joint research. However, according to these companies, intellectual property right was still a significant concern in China, so they could not give the core technology to partner universities, and the existing relationship is built on a strict confidentiality agreement.

Our company is a small size one and cannot afford too much time and material on training junior technicians. However, our experience in recruiting graduates shows there is a serious mismatch between human capital supply and demand in China. It will limit the growth of new and small high-technology firms, which is reflected in that these firms cannot employ suitable graduates, while a large number of graduates cannot find an ideal job. Rather than top-ranked universities, now we might cooperate with some colleges, which are more practice-oriented. (Director, Yuda Co. Ltd, 2012)

\section{5) The role of spatial proximity among firms}

To those firms sharing similar technology, there was a great willingness of smalland medium-sized firms to build relationships with large-sized firms. As a 
company with hefty investment, Dawning has significant expertise in cloud computing, the field in which the Jiangning government has made the most efforts in recent years.

Several companies' representatives have visited our research centre and discussed the potential collaboration opportunities such as Bolikang and Intple. We are already in the process of signing a formal contract with Bolikang, aiming to jointly promote the cloud computing and smart city development of Nanjing. For us, honestly, most of the matched partners/customers are outside of the JETDZ. However, we appreciate the proximity to other firms and they are welcome to visit us. (Director, Dawning Information Industry Co., Ltd, 2012)

However, several companies commented that a mature science park, as they understood it, should be a platform for the development of industrial chains; however, in JETDZ, it is less likely for companies to seek vertical cooperation with their on-site counterparts.

As a small and young firm, we need to outsource some low-skilld but specific projects to other companies. In the US and UK, there are many electronics design consultant companies which consist of 4-5 people but can be responsible for hardware/software development or components procurement. Since the technology level of these companies is relatively low and their scale is usually small, they cannot access parks and zones in China, which usually set high requirements. Moreover, due to a lack of government support and business opportunities, it is difficult for this kind of firm to survive in China at the current stage. (Director, Yuda Co. Ltd, 2012)

A general concern regarding the role of spatial proximity among firms is that the significance of geographical proximity goes down as the number of diversified industries the local government is interested in increases. This circumstance escalates the difficulty for on-site companies to build relationships with each other. Therefore, instead of a place that can be a platform for exchanging knowledge and creating an innovation environment, government-led parks and zones are more like real estate properties, and in this sense on-site firms are like tenants.

Although from the formal perspective, cooperation among firms was not achieved as expected for various reasons, most of the correspondents viewed geographical proximity as an important channel for exchanging information. Some interviewees told us that as new entrepreneurs, they expected to glean experience from the mature companies through well-organised social events. Since most of the firms we interviewed were small in scale and in their infancy, they did not behave proactively to organise events but overwhelmingly depended on the Jiangning government. However, a local officer defended that governments know little about professional knowledge and industrial information. Additionally, he thought the municipal and district-level governments had already attracted a large number of innovative firms to JETDZ and attempted to produce a research and business environment; it should not be 
their responsibility to support and monitor a firm from birth to maturity step by step.

\section{Discussion and conclusion}

Undoubtedly, if one of the motivations for establishing science parks is to set up a physical environment with short distances between universities and industries and among firms (Matthias, 1986), most Chinese science parks have achieved this goal through government-led science park projects. However, through indepth interviews with representatives of high-tech firms, we found that the knowledge transfer from local universities to industries has proved to be successful to a rather limited extent. In reference to the criticism that the contribution of many science parks can only restricted to provide luxury real estate with few synergies between industries and universities (Quintas et al., 1992), there are multiple reasons for explaining this phenomenon in China, including weak intellectual property right protection, strict data and information confidentiality, specific technology fields and unsatisfactory quality of education. Some reasons exist widely, while others only apply to a few cases. Unlike Western experiences such as in the UK, where the Science Park Association can reduce the importance of academic links following a pragmatic mechanism, in China, the existence of universities close to a science park is like a compulsory need for a government-led project. Especially for those development zones or technology districts with numerous small-scale science parks located in newly created urban areas, the role of university campuses is significant, which can make a contribution to local image building.

Apparently, the mixed industrial structure results in inefficiency when it comes to taking advantage of geographical proximity in a science park. The attraction of firms in different technology fields into Cuiping park can be seen as a microcosm in the hierarchical structuring pattern of China's plentiful science parks. This phenomenon raises the root reason for the frequently criticised groundless arrangement of industrial layout in the development zones and technology regions, from district level to municipal level and further from provincial level to national level. From the perspective of firms, especially small-size companies, they appreciate the importance of geographical proximity and consider firms in the same industry as their potential partners. From the stance of government, various industries can open more opportunities to seize potential high-profile firms. In the meantime, it should be noted that although the evidence indicates that there are quite a few collaborations among firms, it is still likely that geographical proximity stimulates social proximity in the sense that the short distance can directly result in the informal network among firms, and there is a potential to produce more space for firms to enhance this network.

In the location selecting process, tenant firms are attracted to Cuiping Park mainly due to pecuniary benefits offered by the district government in the form of deducted rental and tax subsidies as well as land support. In addition, apart from the government's support, human capital, infrastructure facilities and land resources in Jiangning district are also considered important assets. The contribution of government in appealing to and supporting high-technology firms in science parks is a double-edged sword. The positive perspective is that 
government policy can play an unequivocal role in establishing science parks, attracting high-technology firms to science parks and further creating a geographical proximity in science parks. The function of government in China, especially in the lower position of the hierarchical system, is thought to be gradually moving from a traditional centralised political and administrative position to that of a service provider who proactively builds public-private partnerships. The in-depth interviews conducted in this study show that the district-level government plays a key role in building relationships with hightech firms, and their work has been widely acknowledged by the tenant firms. On the other hand, the supportive policy indirectly results in an over-dependency of firms on governments so that the firms ascribe the responsibility of a weak collaboration within parks to the government rather than considering their own problems. Moreover, since most of the newly established technopolises are accompanied with administrative restructuring, in the process of which urban area is enlarged, the expansion of urban construction land due to governmentled zone and park fever has been frequently alarming.

Under different contexts worldwide, several critical discussions have been raised about the extravagant confidence of governments regarding creation of employment, land revenue and economic growth potential (Quintas et al., 1992; Felsenstein, 1994; Storey and Tether, 1998). What distinguishes China is the fact that a large number of high-tech firms have been attracted to science parks by various incentive packages provided by different levels of government, which is likely to distort the original function of science parks as a platform for developing high-tech businesses and promoting academia-industry linkage. In many cases, local governments, especially those at the municipal and district levels, tend to adopt homogeneous strategies in attracting inward investment and high-tech firms, and science parks are becoming a new urban growth machine in this process. The rationale is that under the economic reform and political decentralization, local governments in China have gradually taken over the direct management of local public resources such as land and tax policy. Consequently, unlike the experiences of Hsingchu in Taiwan focussing on semiconductors and the experiences of Bangalore in India prioritizing software development, the mushrooming science parks in China labelled with different administrative levels will result in a disorganized distribution of high-tech firms in terms of their size and developing priority.

Although the science park in this case study may not yet be mature enough for conclusions to be demonstrated because of its young age, it is worth mentioning that the selection of Cuiping Technology and Innovation Park and Jiangning Economic and Technological Development Zone in the city of Nanjing is pertinent to the key features of Chinese's science parks, that is the special government-led hierarchical structure with a "sub-park" mode. It should be noted that this case study is representative of numerous small-scale science parks in China, as well as essential in contributing future research potential as follows. One direction that can be explored is the benefits and side effects of these young science parks for economic development based on data such as employment increases and attraction of foreign direct investment; we could investigate whether the phenomenon of booming science parks is just a good 
"label" or a "signal" of local development. Secondly, in view of the feedback on location choice regarding the living environment rather than the entrepreneurial dimension, there is an opportunity to explore which kinds of local amenities surrounding science parks can best meet the requirements of domestic and returnee entrepreneurs.

\section{Reference:}

Antonelli, Cristiano. "The evolution of the industrial organisation of the production of knowledge." Cambridge Journal of Economics 23, no. 2 (1999): 243260.

Anttiroiko, A. V. "Making of an Asia- Pacific high-technology hub: reflections on the large-scale business site development projects of the Osaka city and the Osaka prefecture." Regional Studies, 43(5) (2009): 759-769.

Appold, Stephen J. "Research parks and the location of industrial research laboratories: an analysis of the effectiveness of a policy intervention." Research Policy 33, no. 2 (2004): 225-243.

Arundel, Anthony, and Aldo Geuna. "Proximity and the use of public science by innovative European firms." Economics of Innovation and New Technology 13, no. 6 (2004): 559-580.

Bakouros, Y.L., Mardas, D.C., Varsakelis, N.C. "Science park, a high tech fantasy? An analysis of the science parks of Greece." Technovation 22 (2002): 123-128.

Bania, Neil, Lindsay N. Calkins, and Douglas R. Dalenberg. "The effects of regional science and technology policy on the geographic distribution of industrial R\&D laboratories." Journal of Regional Science 32, no. 2 (1992): 209-228.

Bartels, C.P.A.and Wolff, J.W.A. Science parken in The Netherlands ŽScience parks in The Netherlands., ESB article, November, 1993.

Bathelt, Harald, Anders Malmberg, and Peter Maskell. "Clusters and knowledge: local buzz, global pipelines and the process of knowledge creation." Progress in Human Geography 28, no. 1 (2004): 31-56.

Beeson, Patricia, and Edward B. Montgomery. The effects of colleges and universities on local labor markets. No. w3280. National Bureau of Economic Research, 1990.

Cao, Cong. "Zhongguancun and China's High-Tech Parks in Transition:"Growing Pains" or "Premature Senility"?." Asian Survey 44, no. 5 (2004): 647-668.

Chan, K. F., and Theresa Lau. "Assessing technology incubator programs in the science park: the good, the bad and the ugly." Technovation 25, no. 10 (2005): 1215-1228.

Chen, H. "Development and spatial distribution of high-tech parks in China." Economic Geography 29, no.11 (2009): 1762-1769 (in Chinese) 
Chen, Stephen, and Chong Ju Choi. "Creating a knowledge-based city: the example of Hsinchu Science Park." Journal of Knowledge Management 8, no. 5 (2004): 73-82.

Cheng, Fangfang, Frank van Oort, Stan Geertman, and Pieter Hooimeijer. "Science Parks and the Co-location of High-tech Small-and Medium-sized Firms in China's Shenzhen." Urban Studies (2013): 0042098013493020.

Chiesa, Vittorio, and Davide Chiaroni. Industrial Clusters in Biotechnology: Driving Forces, Development Processes, and Management Practices. Imperial College Press, 2005.

China Academy of Urban Planning \&Design. Strategic planning study: creating more prosperous and sustainable nanjing. 2004. (In Chinese)

China National School of Administration. Strategic planning study on Nanjing's development since 2005. 2004. (In Chinese).

Felsenstein, Daniel. "University-related science parks-'seedbeds' or 'enclaves' of innovation?." Technovation 14, no. 2 (1994): 93-110.

He, Canfei, YH Dennis Wei, and Fenghua Pan. "Geographical concentration of manufacturing industries in China: The importance of spatial and industrial scales." Eurasian Geography and Economics 48, no. 5 (2007): 603-625.

$\mathrm{Hu}$, Jin-Li, Tsung-Fu Han, Fang-Yu Yeh, and Chi-Liang Lu. "Efficiency of science and technology industrial parks in China." Journal of Management Research 10, no. 3 (2010): 151-166.

Huang, Kuo-Feng, Chwo-Ming Joseph Yu, and Dah-Hsian Seetoo. "Firm innovation in policy-driven parks and spontaneous clusters: the smaller firm the better?." The Journal of Technology Transfer 37, no. 5 (2012): 715-731.

Huang, Yongming, David B. Audretsch, and Megan Hewitt. "Chinese technology transfer policy: The case of the national independent innovation demonstration zone of East Lake." The Journal of Technology Transfer 38, no. 6 (2013): 828-835.

Jaffe, Adam B. Technological opportunity and spillovers of R\&D: evidence from firms' patents, profits and market value. National Bureau of Economic Research, 1986.

Koh, Francis CC, Winston TH Koh, and Feichin Ted Tschang. "An analytical framework for science parks and technology districts with an application to Singapore." Journal of Business Venturing 20, no. 2 (2005): 217-239.

Leamer, Edward E., and Michael Storper. The Economic Geography of the Internet Age. No. w8450. National Bureau of Economic Research, 2001.

Lin, X. Software parks were excessively built in Nanjing. Jiangnan Newspaper (2009) (In chinese). 
Link, Albert N., and Kevin R. Link. "On the growth of US science parks." The journal of technology Transfer 28.1 (2003): 81-85.

Link, Albert N., and John T. Scott. "US university research parks." Journal of Productivity Analysis 25.1-2 (2006): 43-55.

Lo, C. Socialist ideology and urban strategies in China. Urban Geography, 8(5) (1987): 440-458

Macdonald, Stuart. "British science parks: reflections on the politics of high technology." R\&D Management 17, no. 1 (1987): 25-37.

Malecki, Edward J. Technology and economic development: the dynamics of local, regional, and national change, Longman, 1991.

Malerba, F., F. Lissoni, and L. Campanini. "Italy: National policies to promote the development of NTBFs." CESPRI, Bocconi University Eds, Milano, Italy (1995).

Matthias, Peter. Report of the Working Party on the Private Sector Funding of Scientific Research. Advisory Board for the Research Councils, 1986.

Miller, Roger-Emile, and Marcel Cote. Growing the next Silicon Valley: A guide for successful regional planning. Free Press, 1987.

Ministry of Science and Technology of the people's Republic of China (MOST).

"The first 14 high- and new- technology districts upgraded to national-level highand new- technology and industry development zone in 2015." Accessed March 17, 2015. http://most.gov.cn/kjbgz/201503/t20150326_118739.html.

Monck, C.S.P., Porter, R.B., Quintas, P., Storey, D.J., Wynarczyk, P., Science parks and the growth of high technology firms. Croom Helm, London, 1988.

Phan, Phillip H., Donald S. Siegel, and Mike Wright. "Science parks and incubators: observations, synthesis and future research." Journal of business venturing 20.2 (2005): 165-182.

Phillips, S. A. M. and Yeung, H. W. C. "A place for R\&D? The Singapore science park." Urban Studies, 40(4) (2003): 707-732.

PricewaterhouseCoopers. Nanjing Investment Environment Report. (2012).

Qian, Zhu. "Institutions and local growth coalitions in China's urban land reform: The case of Hangzhou High - Technology Zone." Asia Pacific Viewpoint 48, no. 2 (2007): 219-233.

Qian, Zhu. "Master plan, plan adjustment and urban development reality under China's market transition: A case study of Nanjing." Cities 30 (2013): 77-88.

Quintas, Paul, David Wield, and Doreen Massey. "Academic-industry links and innovation: questioning the science park model." Technovation 12, no. 3 (1992): 161-175. 
Ramirez, Matias, Xibao Li, and Weifeng Chen. "Comparing the impact of intra-and inter-regional labour mobility on problem-solving in a Chinese science park." Regional Studies 47, no. 10 (2013): 1734-1751.

Roberts, Joanne. "From know-how to show-how? Questioning the role of information and communication technologies in knowledge transfer."

Technology Analysis \& Strategic Management 12, no. 4 (2000): 429-443.

Shearmur, Richard, and David Doloreux. "Science parks: actors or reactors? Canadian science parks in their urban context." Environment and Planning A 32, no. 6 (2000): 1065-1082.

Smith, H. Lawton. "Universities, innovation, and territorial development: a review of the evidence." Environment and Planning C 25, no. 1 (2007): 98.

Sternberg, R. "Does Location Matter? On the Impact of Innovation Centres on the Development of Innovation Oriented Start-ups." In workshop" Firms Dynamics in High-Technology Industries," ZEW, Mannheim, June, pp. 9-10. 1997.

Storey, David J., and Bruce S. Tether. "Public policy measures to support new technology-based firms in the European Union." Research Policy 26, no. 9 (1998): 1037-1057.

Sutherland, Dylan. "China's science parks: production bases or a tool for institutional reform?." Asia Pacific Business Review 11, no. 1 (2005): 83-104.

Tan, Justin. "Growth of industry clusters and innovation: Lessons from Beijing Zhongguancun Science Park." Journal of Business Venturing 21, no. 6 (2006): 827850 .

Vaidyanathan, Geetha. "Technology parks in a developing country: the case of India." The Journal of Technology Transfer 33.3 (2008): 285-299.

Van Tilburg, J.J., Vorstman, C.M., 1994. Ondernemen met technology ŽEntrepreneurship with technology., Enschede, March.

Vedovello, Conceicao. "Science parks and university-industry interaction: geographical proximity between the agents as a driving force." Technovation 17, no. 9 (1997): 491-531.

Wang, Jici, and Jixian Wang. "An analysis of new-tech agglomeration in Beijing: a new industrial district in the making?." Environment and planning $A 30$, no. 4 (1998): 681-701.

Walcott, Susan M. "Chinese industrial and science parks: bridging the gap." The Professional Geographer 54, no. 3 (2002): 349-364.

Wei, Yehua Dennis. "Zone fever, project fever: development policy, economic transition, and urban expansion in China." Geographical Review 105, no. 2 (2015): 156-177. 
Westhead, Paul, and David J. Storey. An assessment of firms located on and off science parks in the United Kingdom. HM Stationery Office, 1994.

Zhou, Yang. "Reflections on the core problems in the Development Zone:

Evidence from Jiangning District, Nanjing," Modern Urban Research, no.2 (2009): 66-72. [in Chinese]

Zou, Yonghua, and Wanxia Zhao. "Anatomy of Tsinghua University Science Park in China: institutional evolution and assessment." The Journal of Technology Transfer 39, no. 5 (2014): 663-674. 